\title{
EFEKTIVITAS SOCIAL MEDIA INSTAGRAM \#PASARSENENUKM TERHADAP PENINGKATAN PROMOSI UKM DI INDONESIA
}

\author{
Alysha Tri Wardhani ${ }^{1}$, Uljanatunnisa ${ }^{2}$, Yani Hendrayani ${ }^{3}$ \\ alyshatriwrdh@gmail.com¹ㄴ. Uljanatunnisa@gmail.com² ${ }^{2}$,yanihendrayani@upnvj.ac.id ${ }^{3}$ \\ Universitas Pembangunan Nasional "Veteran" Jakarta
}

\begin{abstract}
\#PasarsenenUKM Service is a service on Instagram social media that made public relations Ministry of SME and RI. The purpose this research is to know how much Social Media effectiveness Instagram \#pasarsenenUKM to increase promotion of SMES in Indonesia. The theory used is The Hierarchy of Effects Concept, this theory explains the steps that consumers take to make decisions. The method used is quantitative with this type of an expreslanative research. The chosen population is an Instagram followers @ KemenkopUKM as much as 186,000 people, using Yamane formula and then obtained the sample number of 100 respondents. This research uses questionnaire deployment techniques to get data. Based on the calculation the test results Tobtained t count 11.921 > T table 1.661, it can be concluded that Ho rejected and Ha accepted meaning that Social Media effectiveness the Instagram \#pasarsenenUKM has significant influence on the improvement of SME promotion in Indonesia.
\end{abstract}

Keywords : Effectivity, SMB Promotion, Instagram

\section{PENDAHULUAN}

Di era gobalisasi, teknologi informasi dan komunikasi berperan sangat penting. Dengan menguasai teknologi dan informasi kita cukup memiliki modal untuk menjadi pemenang dalam persaingan global. Adapun hasil dari teknologi dan informasi komunikasi saat ini adalah salah satunya internet. Internet bagaikan sebuah pusat perdagangan terbesar di era globalisasi saat ini. Dengan adanya internet, masyarakat bisa dengan mudah memperoleh informasi yang ada di seluruh belahan dunia. Berdasarkan laporan dari We Are Social, pada tahun 2020 disebutkan bahwa ada 175,4 juta pengguna internet di Indonesia. Dibandingkan tahun sebelumnya, ada kenaikan sebesar $17 \%$ atau 25 juta pengguna internet di negeri ini. Berdasarkan total populasi Indonesia yang berjumlah 272,1 juta jiwa, maka itu artinya $64 \%$ setengah penduduk RI telah merasakan akses ke dunia maya (Haryanto, 2020).

Saat ini sudah banyak jenis platforms media sosial berdasarkan penggunaan dan fungsinya, diantaranya adalah Youtube, Line, Twitter, WhatsApp, Pinterest, Instagram, Snapchat, dll. Platforms yang paling sering digunakan pengguna media sosial dengan persentase Youtube mencapai $88 \%$, WhatsApp sebesar $84 \%$, Faebook sebesar 82\%, dan Instagram sebesar 79\% (Jayani, 2020). Data tersebut membuktikan bahwa Instagram masuk ke dalam urutan empat besar dari banyaknya platforms media sosial. Itu terbukti bahwa masyrakat sudah banyak yang menggunakan Instagram sebagai media untuk berkomunikasi dan mencari informasi yang dibutuhkan.

Dari banyaknya platforms social media, Kementerian Koperasi dan UKM RI pun juga mempunyai social media, salah satunya adalah Instagram. Dari hasil observasi pra penelitian yang dilakukan penulis, mengungkapkan bahwa penggunaan Instagram oleh Kementerian Koperasi dan UKM RI bertujuan untuk memberitahu kegiatan mengenai koperasi, karena zaman sekarang masih ada masyarakat yang belum paham mengenai koperasi, karena pandangan masyarakat mengenai koperasi ialah tradisional atau masih merasa ragu tentang keamanan dalam menyimpan uang mereka. Selain itu masyarakat juga masih merasa takut untuk memulai suatu usaha karena terhambat modal yang sedikit, bunga yang tinggi jika meminjam uang di bank, dan khawatir tidak mendapatkan hak cipta atas produk yang mereka ciptakan. 
Kementerian Koperasi dan Usaha Kecil dan Menengah Republik Indonesia merupakan salah satu Kementerian Republik Indonesia dengan tugas membantu Presiden untuk mengkoordinasikan perumusan kebijakan dan koordinasi pelaksanaan kebijakan pemberdayaan Koperasi dan UMKM (Usaha Mikro Kecil dan Menengah) di Indonesia. Dilansir dari website Kementerian Koperasi dan UKM RI, tugas dari Kementerian Koperasi dan Usaha Kecil dan Menengah Republik Indonesia adalah merumuskan kebijakan pemerintah di bidang pembinaan koperasi dan usaha kecil menengah; mengkoordinasikan dan meningkatkan keterpaduan penyusunan rencana dan program, pemantauan, analisis dan evaluasi di bidang koperasi dan usaha kecil menengah; meningkatkan peran serta masyarakat di bidang koperasi dan usaha kecil menengah; mengkoordinaksikan kegiatan operasioanl lembaga pengembangan sumber daya ekonomi rakyat; dan menyampaikan laporan hasil evaluasi, saran dan pertimbangan di bidang tugas dan fungsinya kepada Presiden.

Akun Instagram yang bernama@KemenkopUKM milik Kementerian Koperasi dan UKM RI, yang dikelola oleh Bagian Humas dan Advokasi Hukum. Adapun tujuan dibuatnya akun Instagram tersebut ialah untuk melaksanakan tugas dan fungsi Humas salah satunya adalah layanan di social media. Layanan melalui social media dengan menggunakan Instagram sedang populer digunakan berbagai instansi baik milik Pemerintah maupun Swasta. Salah satunya adalah akun @KemenkopUKM yang memanfaatkan Instagram untuk melakukan layanan mengenai \#pasarsenenUKM yang bertujuan untuk mengajak masyarakat supaya lebih mempublikasi dan mempromosikan produk atau jasa yang dibuat oleh para pelaku UKM agar lebih banyak lagi masyarakat yang mengetahui produk dan jasa tersebut.

Humas Kementerian Koperasi dan UKM RI dalam melakukan layanan \#pasarsenenUKM, memerlukan sebuah sarana yang sesuai agar dapat diterima dan dipahami oleh masyarakat dengan mudah tanpa terbatas jarak dan waktu, karena seorang praktisi humas atau public relations harus mengikuti perkembangan teknologi komunikasi. Tujuan dari \#pasarsenenUKM di social media Instagram adalah inisiasi dari Humas
Kementerian Koperasi dan UKM RI yang melihat banyaknya peluang produk UKM yang dijual di social media, melalui hal tersebut, social media Instagram @KemenkopUKM ingin membantu mempromosikannya secara gratis di Instagram tersebut.

\#pasarsenenUKM merupakan salah satu program yang dibuat oleh Humas Kementerian Koperasi dan UKM RI yang bertujuan untuk mempromosikan produk UKM di social media yaitu di Instagram @KemenkopUKM. Dengan adanya \#pasarsenenUKM, Kementerian Koperasi dan UKM RI bermaksud untuk mengajak para pelaku UKM untuk mempromosikan produk atau jasa yang dibuatnya.

Dengan adanya \#pasarsenenUKM yang sudah berjalan dari tahun 2017 di social media Instagram milik Kementerian Koperasi dan UKM RI, banyak para pelaku UKM yang ikut mempromosikan produk UKM nya di social medianya dan menggunakan \#pasarsenenUKM agar dilihat oleh admin yang memegang Instagram @ KemenkopUKM.

Dalam hal ini penulis melakukan survey pada followers Instagram @KemenkopUKM dikarenakan penulis ingin mengetahui seberapa besar efektivitas social media Instagram \#pasarsenenUKM yang dibuat oleh Humas Kementerian Koperasi dan UKM RI terhadap para pelaku UKM yang mengikuti akun Instagram @KemenkopUKM.

\section{TINJAUAN PUSTAKA}

Penelitian ini diperlukan dukungan dari hasil - hasil penelitian yang telah ada sebelumnya yang berkaitan dengan penelitian ini, antara lainnya adalah: penelitian dari Zulia Khairani, Efrita Soviyaant, dan Aznuriyandi (2018) menunjukkan bahwa efektivitas promosi pada produk UMKM makanan dan minuman di Kota Pekanbaru di media Instagram pada kategori tinggi, artinya kegiatan promosi yang dilakukan mampu menimbulkan perhatian (attention), ketertarikan (interest), dan feedback (desire) dan sebagian melakukan kegiatan membeli produk dari followers (action).

Sedangkan penelitian dari Yunizar Sri Wulandari, Anna Fatchiya (2017) 
menunjukkan bahwa promosi melalui Twitter efektif dalam menstimulasi perhatian, meningkatkan ketertarikan, menimbulkan keinginan untuk membeli hingga tindakan untuk membeli.

Dengan demikian promosi yang dilakukan melalui social media dari Instagram atau Twitter terlihat efektif karena mampu menimbulkan perhatian, ketertarikan, dan feedback dan sebagian melakukan kegiatan membeli produk.

Dalam penelitian ini konsep - konsep yang digunakan adalah sebagai berikut, Efektivitas dengan definisi menurut Sumanth (dalam Darsono, dkk. 2011) menjelaskan bahwa efektivitas adalah seberapa baik tujuan yang dapat dicapai, merupakan prestasi yang dicapai dibandingkan dengan yang mungkin dicapai, dengan tetap mempertahankan mutu.

Public Relations, menurut Mukarom \& Laksana (2015) Public Relations adalah seni meciptakan pengertian publik yang lebih baik sehingga dapat memperdalam kepercayaan publik terhadap suatu individu atau organisasi. Aktivitas public relations sehari - hari adalah menyelenggrakan kounikasi timbal balik (two way traffic communications) antar lembaga dan pihak publik yang bertujuan menciptakan saling pengertian dan dukungan bagi tercapainya tujuan tertentu, kebijakan, kegiatan produksi, demi kemajuan lembaga atau citra positif lembaga bersangkutan.

Humas Pemerintahan, menurut Kusumastuti (2004) Humas Pemerintah pada pada dasarnya tidak bersifat politis. Bagian humas di institusi pemerintahan dibentuk untuk mempublikasikan atau mempromosikan kebijakan - kebijakan mereka. Memberi informasi secara teratur tentang kebijakan, rencana - rencana, serta hasil - hasil kerja institusi seta memberi pengertian kepada masyarakat tentang peraturan dan perundang - undangan dan segala sesuatunya yang berpengaruh terhadap kehidupan masyarakat. Selain keluar, humas pemerintahan, dan politik juga harus memungkinkan untuk memberi masukan dan saran bagi pejabat tentang segala informasi yang diperlukan dan reaksi atau kemungkinan reaksi masyarakat akan kebijakan institusi, baik yang sedang dilaksanakan, akan dilaksanakan, ataupun yang sedang diusulkan.
Media Sosial, menurut Shirky (2008) dalam Nasrullah (2015) menjelaskan bahwa media sosial dan perangkat lunak sosial merupakan alat untuk meningkatkan kemampuan pengguna untuk berbagi (to share), bekerja sama (to co-operate) di antara pengguna dan melakukan tindakan secara kolektif yang semuanya berada di luar kerangka institusional maupun organisai.

Instagram, menurut Nisrina (2015) mengungkapkan Instagram adalah sebuah aplikasi yang digunakan untuk membagi bagikan foto dan video. Instagram sendiri masih merupakan bagian dari Facebook yang memungkinkan teman Facebook kita memfollow - akun Instagram kita. Makin populernya Instagram sebagai aplikasi yang digunakan untuk membagi foto membuat banyak pengguna yang turun ke bisinis online turut mempromosikan produk - produknya lewat Instagram.

Promosi, menurut Herlambang (2014) mengatakan bahwa promosi merupakan salah satu komponen dari kegiatan komunikasi pemasaran, sejalan dengan periklanan, humas, dan penjualan personal. Promosi adalah aktivitas pemasaran yang mengusulkan nilai tambah dari suatu produk untuk mendapatkan lebih dari sekedar yang ada dari nilai produk yang mendorong pembelian konsumen, efektivitas, penjualan, atau mendorong upaya yang dilakukan oleh tenaga penjual.

UKM, menurut Undang-Undang Bab I Pasal 1 Nomor 20 Tahun 2008 tentang Usaha Mikro, Kecil, dan Menengah (UMKM), maka: Usaha Mikro adalah usaha produktif milik orang perorangan dan/atau badan usaha perorangan yang memenuhi kriteria Usaha Mikro; Usaha Kecil adalah usaha ekonomi produktif yang berdiri sendiri, yang dilakukan oleh orang perorangan atau badan usaha yang bukan cabang perusahaan yang dimiliki, dikuasai, atau menjadi bagian baik langsung maupun tidak langsung dari Usaha Menengah atau Usaha Besar yang memenuhi kriteria Usaha Kecil; Usaha Menengah adalah usaha ekonomi produktif yang berdiri sendiri, yang dilakukan oleh orang perorangan atau badan usaha yang bukan merupakan anak perusahaan atau cabang perusahaan yang dimiliki, dikuasai, atau menjadi bagian baik langsung maupun tidak langsung dengan Usaha Kecil atau Usaha Besar dengan jumlah kekayaan bersih atau hasil penjualan tahunan. 
Hasil penelitian yang dilakukan berkaitan dengan the hierarchy of effects. Dalam Ilham (2006) mengatakan bahwa istilah hierarchy of effects concept untuk pertama kali diperkenalkan oleh Lavidge dan Steiner pada tahun 1961. Maksud dari the hierarchy of effects ini untuk mengetahui tingkat pemahaman dan pengetahuan seseorang melalui konsep AIDA yang terdiri dari Attentions (perhatian), Interest (menarik), Desire (keinginan) dan Action (aksi). Dalam penelitian ini, alasan penulis memilih konsep AIDA karena ingin mengukur seberapa berhasilnya sebuah layanan yang dilihat melalui efektivitas serta konsep AIDA. Maka dari itu, bagaimana pun layanan yang dibuat harus dikemas secara unik agar masyarakat bisa menerima pesan dari layanan yang dibuat.

\section{METODE PENELITIAN}

Penelitian ini menggunakan pendekatan kuantitatif dengan jenis penelitian ekspalanatif, paradigma pada penelitian ini adalah paradigma positivisme dan metode penelitian penulis menggunakan metode survey.

Penelitian ini dilakukan pada followers Instagram @KemenkopUKM. Data Primer adalah data yang diperoleh secara langsung dari objek penelitian perorangan, kelompok, dan organisasi dengan menggunakan kuesioner yang dibagikan kepada responden. Data Sekunder adalah data yang sudah tersedia sehingga kita tinggal mencari dan mengumpulkannya, seperti studi pustaka, buku, internet serta dokumen dan khsusunya data yang memiliki hubungan dengan penelitian yang sedang diteliti.

Teknik penarikan sampel pada penelitian ini adalah Teknik Probability Sampling, menurut Sugiyono (2013) yaitu teknik pengambilan sampel yang memberikan peluang yang sama bagi setiap setiap unsur (anggota) populasi untuk dipilih menjadi sampel. Penelitian ini memilih jenis simple random sampling dimana dikatakan simple (sederhana) karena pengambilan anggota sampel dari populasi dilakukan secara acak tanpa memperhatikan strata yang ada dalam populasi itu.

Klasifikasi variabel dalam penelitian ini ialah menggunakan 2 variabel sebagai berikut, suatu variabel dikatakan bebas (Independent) merupakan variabel yang mempengaruhi atau menjadi sebab perubahannya atau timbul suatu variabel terikat (Dependent), dalam penelitian ini penulis menetapkan variabel bebas (Independent) ialah "Efektivitas Social Media". Sedangkan variabel terikat (Dependent) merupakan variabel yang dipengaruhi atau menjadi akibat, karena adanya variabel bebas (Independent). Dalam penelitian ini variabel terikat (Dependent) "Promosi UKM".

Teknik analisis data yang digunakan dalam penelitian ini adalah : Pertama, Uji Korelasi, dalam analisis korelasi yang dicari adalah koefisien korelasi yaitu angka yang menyatakan kekuatan hubungan linear antar variabel yang berbeda. Kedua, Koefisien Determinasi untuk mengetahui persentase pengaruh yang telah di uji memakai uji korelasi. Analisis determinasi juga menjelaskan bahwa besarnya kontribusi yang diberikan variabel independen terhadap variabel dependen. Ketiga, Uji Regresi menurut Kriyantono (2012) mengatakan bahwa korelasi dan regresi keduanya memiliki hubungan yang erat setiap regresi dipastikan terdapat korelasinya. Tetapi belum tentu korelasinya dilanjutkan dengan regresi. Analisis regresi dilakukan jika korelasi antara dua variabel mempunyai hubungan kasual (sebab akibat) atau hubungan fungsional. Terakhir adalah Uji Hipotesis untuk mengetahui apakah variabel bebas (Independent) memiliki hubungan signifikan atau tidak dengan variabel terikat (Dependent) secara individual untuk setiap variabel.

\section{HASIL PENELITIAN}

Dibawah ini adalah menjelaskan tentang karteristik responden yang terdiri dari usia responden, jenis kelamin responden, dan pendidikan terakhir responden menjadi pengikut/ followers Instagram @KemenkopUKM. Akan dijelaskan pada bagian dibawah ini.

Pertama, karakteristik responden berdasarkan usia. Karakteristik ini membagi klasifikasi usia responden dari 100 responden antara lain 7 responden berumur 15 - 20 tahun dengan persentase $(7 \%), 31$ responden berumur $20-25$ tahun dengan persentase (31\%), 30 responden berumur $25-30$ tahun 
dengan persentase $(30 \%), 17$ responden berumur $30-35$ tahun dengan persentase (17\%), 6 responden berumur 35 - 40 tahun dengan persentase $(6 \%)$, dan 9 responden berumur $>40$ tahun dengan persentase $(9 \%)$. Dari hasil tersebut responden terbanyak adalah usia $20-25$ tahun dengan persentase $31 \%$ dimana usia tersebut adalah masa emas ketika merintis sebuah bisnis, dimana saat umur itu mereka memiliki ide - ide cemerlang, energi tak terbatas, dan berpikiran tajam (Hasibuan, 2018).

Kedua, karakteristik responden berdasarkan jenis kelamin, pada karakteristik ini menunjukkan bahwa sebanyak 44 responden dengan persentase (44\%) berjenis kelamin laki - laki sedangakan sebanyak 56 responden dengan persentase $(56 \%)$ berjenis kelamin perempuan, yang menunjukkan bahwa kreasi secara naluriah perempuan seringkali berhasil menggerekkan perekonomian dalam usaha skala kecil rumahan. Tangan - tangan kreatif inilah yang berhasil menciptakan revolusi kecil dari dapur dan ponsel pintarnya, serta ketangguhan dalam berbisnis tidak bisa diragukan lagi. Bisnis rumahan tersebut menjelma sebagai usaha kecil dan menenga (UKM) yang nantinya akan tersebar di seluruh Indonesia (Devita, 2019).

Ketiga, karakteristik responden berdasarkan pendidikan terakhir. Karakteristik ini membagi klasifikasi pendidikan terakhir dari 100 responden antara lain 2 responden dengan pendidikan terakhir SMP dengan persentase (2\%), 51 responden dengan pendidikan terakhir SMA dengan persentase (51\%), 12 responden dengan pendidikan terakhir D3 dengan persentase (12\%), dan 35 responden dengan pendidikan D4/S1 dengan persentase $(35 \%)$. Dari hasil tersebut responden terbanyak adalah berpendidikan terakhir SMA.

Analisis data yang digunakan dalam penelitian ini adalah metode analisis regresi sederhana. Dalam penelitian ini terdapat satu variabel bebas yaitu Efektivitas Social Media dan satu variabel terikat yaitu Promosi UKM.

Dalam penelitian ini, uji analisis korelasi dijelaskan bahwa terdapat korelasi antara variabel X (Efektivitas Social Media) dengan variabel Y (Promosi UKM), dengan koefisien $r$ hitung sebesar 0,769. Dari hasil korelasi tersebut menunjukan bahwa nilai tersebut memiliki hubungan yang kuat, karena nilai $r$ hitung terletak diantara $0,600-0,799$ yang termasuk pada kategori (Kuat). Sehingga dapat disimpulkan bahwa terdapat hubungan yang cukup kuat antara variabel $\mathrm{X}$ dengan variabel Y yaitu sebesar 0,769 .

Setelah itu dihitung seberapa besar nilai dari koefisien determinasi, diketahui nilai Korelasi $(\mathrm{R})=0,769$ dan nilai $\mathrm{R}$ Square (yang merupakan pengkuadratan nilai korelasi) yaitu 0,591 yang bila dipersenkan menjadi $59 \%$. Maka dapat disimpulkan bahwa 59\% Promosi UKM (variabel Y) ditentukan oleh Efektivitas Social Media (variabel X). Sisanya yang berjumlah $41 \%$ ditentukan oleh faktor lain yang tidak diteliti.

Hasil dari uji regresi dapat diketahui adanya pengaruh antara Efektivitas Social Media (variabel X) dengan Promosi UKM (variabel Y) dan disimpulkan bahwa Efektivitas Social Media (Variabel X) tidak mengalami perubahan maka Promosi UKM (variabel Y) bernilai 7.252 dikarenakan hasil "b" positif (+). Maka angka variabel Promosi UKM menaik sebesar 0,814. Sehingga dapat dikatakan bahwa semakin tinggi Efektivitas Social Media Instagram \#pasarsenenUKM maka semakin tinggi Promosi UKM di Indonesia.

Hasil dari uji hipotesis adalah penentuan kesimpulan signifikan dengan membandingkan $\mathrm{t}$ hitung dengan $\mathrm{t}$ tabel yaitu penentuan dari level of signification, dari $\mathrm{t}$ tabel nilainya ditentukan pada tingkat signifikasi 0,10 dan $\mathrm{df}=\mathrm{n}-2$, yaitu $100-2=$ 98. Dengan demikian t tabel yaitu 1,661. Berdasarkan perhitungan tersebut, dapat diketahui hasil perhitungan $\mathrm{t}$ hitung $>\mathrm{t}$ tabel yaitu 11,912 > 1,661. Maka dapat disimpulkan Ho ditolak dan Ha diterima yang berarti bahwa Efektivitas Social Media Instagram \#pasarsenenUKM memiliki pengaruh yang signifikann terhadap Promosi UKM di Indonesia.

\section{PEMBAHASAN}

Berdasarkan penelitian yang telah dilakukan penulis yang berjudul Efektivitas Social Media Instagram \#pasarsenenUKM terhadap peningkatan Promosi UKM di Indonesia. Penelitian ini dilakukan untuk mengetahui seberapa besar Efektivitas Social 
Media Instagram \#pasarsenenUKM terhadap peningkatan Promosi UKM di Indonesia.

Layanan \#pasarsenenUKM yang merupakan inisiasi dari Humas Kementerian Koperasi dan UKM RI sudah berjalan dari tahun 2017 dengan tujuan untuk membantu mempromosikan produk/jasa dari para pelaku UKM di Instagram @ KemenkopUKM. Selain itu, layanan \#pasarsenenUKM merupakan wujud bahwa Kementerian Koperasi dan UKM RI sadar mengenai pentingnya media sosial, dan akhirnya membantu promosi melalui media sosial. Program selanjutnya dari layanan \#pasarsenenUKM adalah temu UKM yang produknya pernah mengikuti \#pasarsenenUKM dan di undang dalam pameran tertentu.

Cara untuk mengikuti layanan \#pasarsenenUKM adalah upload foto produk UKM di akun Instagram masing-masing setiap hari Senin antara pukul 08.00 - 12.00 WIB; berikan caption/penjelasan produk UKM dengan jelas beserta kontak yang bisa dihubungi; dan tag akun Instagram @KemenkopUKM disertai hastag \#pasarsenenUKM. Selain itu ada syarat dan ketentuan untuk mengikuti layanan \#pasarsenenUKM antara lain: follow akun media sosial @KemenkopUKM; produk UKM harus asli Indonesia; produk UKM tidak melanggar hukum; foto produk harus jelas, asli dan tidak mengambil foto orang lain.

Sejak diluncurkan layanan \#pasarsenenUKM, banyak para pelaku UKM yang setuju dan berminat untuk bergabung di \#pasarsenenUKM yang ada di Instagram. Dari hasil penelitian, terdapat $60 \%$ dari responden setuju dengan layanan \#pasarsenenUKM memberikan manfaat yang sangat besar bagi para pelaku UKM, selain itu juga untuk memajukan kesejahteraan UKM di Indonesia. Dengan adanyan layanan \#pasarsenenUKM di Instagram, lebih memudahkan masyarakat serta pengikut Instagram @ KemenkopUKM untuk mencari produk UKM melalui layanan \#pasarsenenUKM.

Program lanjutan dari \#pasarsenenUKM yaitu diadakannya pertemuan, pelatihan, dan promosi yang sangat bermanfaat bagi para pelaku UKM. Mereka mendapat banyak masukan sebagai inspirasi untuk meningkatkan produk sekaligus juga income. Para pelaku
UKM mendapatkan pembekalan dari Kementerian Koperasi dan UKM RI untuk meningkatkan kualitas dan kuantitas produk. Dalam pertemuan tersebut, sesame pelaku UKM juga bisa saling sharing dan support. Pertemuan dan promosi tingkat nasional tersebut sebaiknya diadakan lebih sering dan kontinu, misalnya per 3 bulan dengan harapan kesulitan yang dihadapin pelaku UKM bisa diatasi segera bersama Kementerian Koperasi dan UKM RI, demikian juga Kementerian Koperasi dan UKM RI bisa mengevaluasi UKM. Begitu juga dengan dinas koperasi tingkat wilayah dan daerah sudah seharusnya mendukung layanan \#pasarsenenUKM dan diharapkan pelaku UKM di daerah bisa semakin banyak. Hal ini bisa meningkatkan perekonomian perekonomian masyarakat, mengurangi pengangguran dan mengurangi urbanisasi.

Penelitian ini menggunakan metode survey dengan menggunakan kuesioner yang dikirimkan melalui direct message kepada followers Instagram @ KemenkopUKM dengan jumlah populasi sebanyak 186.000 orang dan sampel sebanyak 100 orang, dengan karakterisitik responden laki - laki dan perempuan yang berusia antara 15 tahun sampai $>40$ tahun dengan pendidikan terakhir SD sampai D4/S1. Penulis menggunakan variabel X yaitu (Efektivitas Social Media) dan variabel Y yaitu (Promosi UKM).

Dari hasil penelitian yang menjelaskan mengenai karakteristik responden khususnya usia, penulis berkesimpulan bahwa responden paling banyak adalah berusia 20 - 25 tahun dengan persentase $31 \%$. Dengan begitu membuktikan bahwa mayoritas pelaku UKM adalah berusia $20-25$ tahun dimana usia tersebut adalah masa emas ketika memulai sebuah bisnis/usaha, saat umur tersebut mereka memiliki ide - ide cemerlang, energi tak terbatas dan juga sudah mengerti menggunakan media sosial untuk kegiatan yang positif.

Dari layanan \#pasarsenenUKM tersebut, penulis ingin mengetahui dan mengukur seberapa besar efektif layanan \#pasarsenenUKM yang dibuat oleh Humas Kementerian Koperasi dan UKM RI. Dengan menggunakan variabel X (Efektivitas Social Media). Sumanth (dalam Darsono, dkk. 2011) menjelaskan bahwa efektivitas adalah seberapa 
baik tujuan yang dapat dicapai, merupakan prestasi yang dicapai dibandingkan dengan yang mungkin dicapai, dengan tetap mempertahankan mutu.

Serta penulis juga menggunakan variabel Y (Promosi UKM) dimana promosi menurut Zimmener dalam Rangkuti (2009) adalah segala bentuk komunikasi persuasi yang dirancang untuk menginformasikan pelanggan tentang produk atau jasa dan untuk mempengaruhi mereka agar membeli barang atau jasa tersebut mencangkup publisitas dan penjualan.

Teori dalam penelitian ini menggunakan the hierarchy of effects, merupakan sebuah teori yang didalamnya terdapat tiga tingkatan dasar untuk mengetahui dimana posisi pelanggan atau khalayak merespon dan memahami suatu produk dari hasil interaksi mereka lewat komunikasi pemasaran, diantaranya adalah tahap knowing (mengetahui atau kenal), tahap feelings (merasakan atau hasrat), dan tahap actions (tindakan terpengaruh). Ada banyak konsep untuk mengetahui tingkat pemahaman dan pengetahuan pelanggan di dalam the hierarchy of effects, salah satunya adalah penulis memilih konsep AIDA (Attentions, Interest, Desire, Action).

Humas Kementerian Koperasi dan UKM RI membuat layanan \#pasarsenenUKM di social media untuk mencuri perhatian (attentions) para pengikut nya di Instagram $@$ KemenkopUKM. Dari unggahan tersebut di social media, membuat para pengikutnya menjadi tertarik (interest) terhadap layanan \#pasarsenenUKM. Setelah ada rasa tertarik, timbulah rasa keinginan (desire) untuk mengikuti layanan \#pasarsenenUKM, yang akhirnya pengikut Instagram @ KemenkopUKM melakukan aksi (action) untuk memposting serta mempromosikan produk UKM nya di social medianya dengan menyertakan \#pasarsenenUKM supaya bisa dilihat oleh banyak orang. Dengan begitu konsep AIDA berhasil dalam mengukur seberapa besar efektif sebuah layanan yang dibuat.

\section{KESIMPULAN}

Berdasarkan hasil penelitian dan pembahasan mengenai Efektivitas Social Media Instagram \#pasarsenenUKM terhadap peningkatan Promosi UKM di Indonesia yang diketahui terdapat hubungan dan pengaruh yang kuat. Jumlah populasi pada penelitian ini yaitu 186.000 dan sampel pada penelitian ini yaitu 100 responden dengan menggunakan teknik probability sampling dengan menggunakan jenis teknik simple random sampling. Pembahasan yang didapat melalui penyebaran kuesioner yang selanjutnya data tersebut diolah dengan menggunakan program Windows Statistic Program For Social Science (SPSS) versi 22, maka dapat disimpulkan :

1. Kelebihan promosi di Instagram sangat menakjubkan, dengan artian diunggah dengan gambar dan dijelaskan dengan deskripsi produk yang detail, memudahkan bagi penjual dan pembeli serta penjualanan produk menjadi lebih berkembang pesat.

2. Berdasarkan hasil pengumpulan data yang telah diisi oleh responden dapat disimpulkan bahwa sebagaian besar responden menyatakan setuju dengan layanan \#pasarsenenUKM yang dibuat oleh Humas Kementerian Koperasi dan UKM RI serta direspon oleh pengikut Instagram @KemenkopUKM dilihat dari banyaknya pengikut Instagram @KemenkopUKM yang mengikuti \#pasarsenenUKM di social media.

3. Layanan \#pasarsenenUKM memudahkan pelaku UKM untuk mempromosikan produk UKM nya di tingkat nasional dan dapat diakses oleh berbagai macam kalangan masyarakat diluar tingkat nasional.

4. Konsep AIDA dalam penelitian ini perannya sangatlah penting, karena digunakan sebagai landasan penelitian serta untuk mengukur seberapa berhasilkah sebuah efektivitas suatu layanan.

5. Pada hasil uji korelasi dalam penelitian ini, kesimpulannya terhadap hubungan antara variabel $\mathrm{X}$ (Efektivitas Social Media) dengan variabel $\mathrm{Y}$ (Promosi UKM) memiliki hubungan yang kuat.

6. Pada hasil uji regresi yang sudah diteliti maka dapat disimpulkan bahwa hasil yang didapatkan yaitu $\mathrm{Y}=7.252+0,814 \mathrm{x}$, sehingga jika skor variabel $\mathrm{X}$ (Efektivitas Social Media) tidak mengalami perubahan, 
maka variabel Y (Promosi UKM) bernilai 7.252, hal itu dikarenakan hasil "b" positif (+) maka angka variabel Promosi UKM sebesar 0,814, sehingga dapat disimpulkan semakin kuat Efektivitas Social Media Instagram \#pasarsenenUKM maka semakin kuat mempengaruhi tingkat Promosi UKM di Indonesia.

7. Pada hasil uji determinasi yang sudah diteliti maka dapat disimpulkan bahwa terdapat Efektivitas Social Media (variabel $\mathrm{X}$ ) terhadap Promosi UKM (variabel Y) yang diketahui nilai Korelasi $(\mathrm{R})=0,769$ dan nilai $\mathrm{R}$ Square (yang merupakan pengkuadratan nilai korelasi) yaitu 0,591 yang bila dipersenkan menjadi 59\%. Maka dapat disimpulkan bahwa 59\% Promosi UKM (variabel Y) ditentukan oleh Efektivitas Social Media (variabel X). Sisanya yang berjumlah $41 \%$ ditentukan oleh faktor yang tidak diteliti.

8. Berdasarkan hasil uji hipotesis terdapat pengaruh yang signifikan antara Efektivitas Social Media Instagram \#pasarsenenUKM (variabel $X$ ) terhadap Promosi UKM (variabel Y) maka dapat disimpulkan Ho ditolak dan Ha diterima.

\section{DAFTAR PUSTAKA}

Darsono dan Tjatjuk S, 2011, Sumber Daya Manusia Abad 21. Nusantara: Jakarta.

Devita, I, Perempuan Berdaya, 2019, Melek Hukum Usaha. https://www.google.co.id/amp/s/irmad evita.com/amp/2019/perempuanberdaya-melek-hukum-usaha-2, April 2020 (14:45).

Haryanto, A.T, 2020, Riset: Ada 175,2 Juta Pengguna Internet di Indonesia. https://m.detik.com/inet/cyberlife/d4907674/riset-ada-1752-jutapengguna-internet-di-indonesia, April 2020 (16:25)

Hasibuan, L, 2018, Di Usia Berapa Para Pengusaha Menuai Kesuksesannya?. https://www.cnbcindonesia.com/entrep reneur/20180510215858-25-14442/diusia-berapa-para-pengusaha-menuaikesuksesannya, 17 April 2020 (14:23).
Herlambang, S, 2014, Basic Marketing (Dasar - dasar Pemasaran) : Cara Mudah Memahami Ilmu Pemasaran. Yogyakarta: Gosyen Publishing

Jayani, D.H, 2020, 10 Media Sosial yang Paling Sering Digunakan di Indonesia. https://databoks.katadata.co.id/datapu blish/2020/02/26/10-media-sosialyang-paling-sering-digunakan-diindonesia, 18 April April 2020 $(17: 05)$

Kementerian Koperasi dan UKM RI, 2018, Tentang Kementerian Koperasi dan UKM.

http://www.depkop.go.id/kementeriankukm, 17 April 2020 (12:45).

Kriyantono, R, 2012, Teknik Praktik Riset Komunikasi: Disertai Contoh Praktis Riset Media, Public Relations,Advertising, Komunikasi Organisasi, Komunikasi Pemasaran. Jakarta: Kencana.

Kusumastuti, F, 2004, Dasar - Dasar Hubungan Masyarakat. Bogor: Penerbit Ghalia Indonesia.

Mukarom, Z dan Laksana, M.W, 2015, Manajemen Public Relations Panduan Efektif Pengelolaan Hubungan Masyarakat. Bandung: Pustaka Setia.

Nasrullah, R, 2015, Media sosial : Perspektif komunikasi, budaya, dan sosioteknologi. Bandung: Simbiosa Rekatama Media.

Nisrina, M, 2015, Bisnis Online, Manfaat Media sosial dalam meraup uang. Yogyakarta: Kobis.

Prisgunanto, I, 2006, Komunikasi Pemasaran Strategi dan Taktik dilengkapi Analisis SOSTAC \&STOP-SIT. Jakarta: Ghalia Indonesia.

Rangkuti, F, 2009, Strategi Promosi Yang Kreatif dan Analisis Kasus Integrated Marketing Communictaion. Jakarta: PT. Gramedia Pustaka Utama.

Sugiyono, 2013, Metode Penelitian Kombinasi : Mixed Methods. Bandung: Alfabeta. 
Undang-Undang Republik Indonesia Nomor 20 Tahun 2008, Usaha Mikro, Kecil, Dan Menengah, Lembaran Negara Republik Indonesia Nomor 4866.

Yunizar Sri Wulandari, A. F, Efektivitas Promosi Melalui Twitter pada Perusahaan Parisiwata Bahari "Ibu Penyu" dalam Jurnal Sains Komunikasi dan Pengembangan Masyarakat, Vol. 1 (2) , 195 - 208, nomer Agustus 2017.

Zulia Khairani, E. S, Efektivitas Promosi Melalui Instagram Pada UMKM Sektor Makanan Dan Minuman Di Kota Pekanbaru dalam Jurnal Benefita 3(2), 239 - 247, nomer Juli 2018. 